\title{
2D Frameworks Self-assembled From a Hydrazone Ligand and Azide Salts: Synthesis, Structures, and Luminescent Property
}

Peng Wang, ${ }^{\dagger}$ Yu-Shan Wu, ${ }^{\dagger}$ Xiao-Meng Han, Shan-Shan Zhao and Jie Qin*

\author{
School of Life Sciences, Shandong University of Technology, Zibo 255049, P. R. China \\ * Corresponding author: E-mail: qinjietutu@ 163.com \\ Tel.: 0086-533-2780271; Fax: 0086-533-2781329
}

Received: 08-02-2017

${ }^{\dagger}$ These authors contributed equally to this work.

\begin{abstract}
Three metal-organic coordination polymers $\left\{\left[\mathrm{Cu}(\mathrm{L})\left(\mathrm{N}_{3}\right)\right] \cdot\left(\mathrm{H}_{2} \mathrm{O}\right)_{0.25}\right\}_{\mathrm{n}}(\mathbf{1}), \quad\left\{\left[\mathrm{Zn}(\mathrm{L})\left(\mathrm{N}_{3}\right)\right] \cdot\left(\mathrm{H}_{2} \mathrm{O}\right)_{0.5}\right\}_{\mathrm{n}}(\mathbf{2})$ and $\left[\mathrm{Cd}_{2}(\mathrm{~L})_{2}\left(\mathrm{~N}_{3}\right)_{2}\left(\mathrm{H}_{2} \mathrm{O}\right)\right]_{\mathrm{n}}(3)$ have been synthesized from hydrazone ligand $N^{\prime}$-(1-(pyrazin-2-yl)ethylidene)isonicotinohydrazide (HL), $\mathrm{NaN}_{3}$ and corresponding metal nitrates. Complexes were characterized by elemental analysis, IR spectroscopy and single-crystal X-ray diffraction. All three complexes feature $2 \mathrm{D}$ coordination network in which $\mathbf{L}^{1-}$ acts as NNON tetradentate ligand and azide acts as end-on bridging ligand. In complexes $\mathbf{1}$ and $\mathbf{2}$, only intra-sheet hydrogen bonding interactions are found, while the hydrogen bonding interactions between water molecules and host framework result in 3D network for 3. In addition, complexes $\mathbf{2}$ and $\mathbf{3}$ exhibited intense fluorescent emissions in the solid state at room temperature.
\end{abstract}

Keywords: Hydrazone; azide; crystal structure; luminescence property

\section{Introduction}

Metal compounds have attracted considerable interest because of their fascinating structures, ${ }^{1}$ and functional applications in many research fields such as adsorption, ${ }^{2}$ gas storage and separation, ${ }^{3,4}$ photoluminescence, ${ }^{5}$ and ion exchange. ${ }^{6,7}$ The organic ligands are considered to be the most important factor that affects the structures and properties of the coordination polymers. ${ }^{8}$

Hydrazone ligands obtained from condensation reaction of aldehydes (or ketones) and hydrazide are an important class of Schiff bases. ${ }^{9}$ We have been interested in coordination compounds involving hydrazone ligands owning to their facile keto-enol tautomerization, the versatile coordination modes, and the strong hydrogen-bonding capability. In previous studies, we synthesized a series of complexes derived from Schiff bases with metal chloride, acetate or nitrate. These complexes showed mononuclear, 1D chain or 3D network. ${ }^{10-12}$

Azide has been demonstrated as the most common used linear ligand. ${ }^{13}$ In the azide complexes, the mono- coordinated, the bidentate including end-on $\left(\mu_{1,1}-\mathrm{N}_{3}^{-}\right)$ and the end-to-end $\left(\mu_{1,3}-\mathrm{N}_{3}{ }^{-}\right)$bridging modes are frequently observed. ${ }^{13-15}$ While the azide group may also function in triply or quadruply bridging modes. ${ }^{16,17}$ So, the complexes derived from hydrazone ligands and azide are good candidates allowing the access to intriguing architectures.

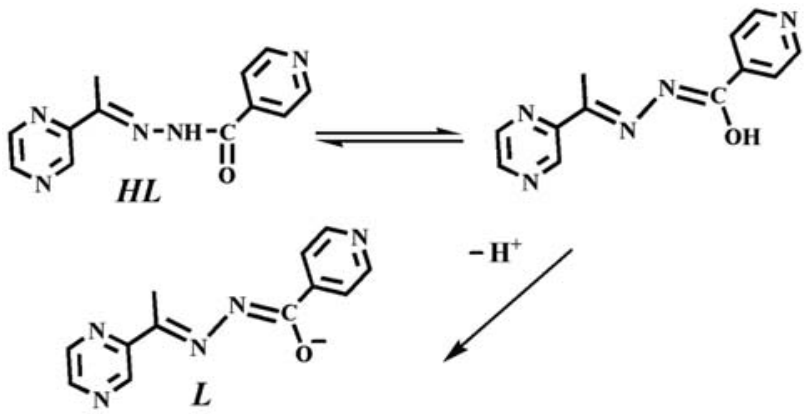

Scheme 1. Tautomerization and deprotonation of HL. 
Recently Shaabani and coworkers reported $\mathrm{Cr}(\mathrm{III})$, $\mathrm{Mn}$ (II) and $\mathrm{Fe}$ (III) complexes with 4-hydroxy- $N$ '-((pyridin-2-yl)-methylene)benzohydrazide and azide as bridging ligands. These three complexes showed mononuclear or dinuclear structure with moderate antimicrobial activity. ${ }^{18} \mathrm{Xu}$ and coworkers reported a series of copper complexes showing antitumor activities based on $N^{\prime}$-(1-(pyrazin-2-yl)ethylidene)isonicotinohydrazide (HL) (Scheme 1). ${ }^{19}$ In this paper, we were prompted to study the coordination chemistry of $\mathbf{H L}$ in the presence of azide. Herein three complexes namely $\left\{\left[\mathrm{Cu}(\mathrm{L})\left(\mathrm{N}_{3}\right)\right]\left(\mathrm{H}_{2} \mathrm{O}\right)_{0.25}\right\}_{\mathrm{n}}(\mathbf{1})$, $\left\{\left[\mathrm{Zn}(\mathrm{L})\left(\mathrm{N}_{3}\right)\right] \cdot\left(\mathrm{H}_{2} \mathrm{O}\right)_{0.25}\right\}_{\mathrm{n}}(\mathbf{2})$ and $\left[\mathrm{Cd}_{2}(\mathbf{L})_{2}\left(\mathrm{~N}_{3}\right)_{2}\left(\mathrm{H}_{2} \mathrm{O}\right)\right]_{\mathrm{n}}$ (3) were synthesized, their crystal structure and luminescence properties were also studied.

\section{Experimental}

\section{1. Materials and Measurements}

The chemicals utilized in this investigation such as 2-acetylpyrazine, isoniazid, $\mathrm{Cu}\left(\mathrm{NO}_{3}\right)_{2} \cdot 3 \mathrm{H}_{2} \mathrm{O}, \mathrm{Zn}\left(\mathrm{NO}_{3}\right)_{2}$ - $6 \mathrm{H}_{2} \mathrm{O}$ and $\mathrm{Cd}\left(\mathrm{NO}_{3}\right)_{2} \cdot 4 \mathrm{H}_{2} \mathrm{O}$ were commercially available and purchased from Aladdin Industrial Corporation (China). $\mathrm{NaN}_{3}$ was purchased from Xiya Reagent (China). $N^{\prime}$-(1-(pyrazin-2-yl)ethyl-idene)isonicotinohydrazide (HL) was prepared according to the literature. ${ }^{12}$ Elemental analyses $(\mathrm{C}, \mathrm{H}$ and $\mathrm{N}$ ) were performed using a Perkine Elmer 240 elemental analyzer. IR spectra were recorded on a FT-IR Nicolet 5700 spectrometer from 4000 to $400 \mathrm{~cm}^{-1}$ with $\mathrm{KBr}$ pellets. Fluorescence spectra were obtained using Cary Eclipse spectrofluorimeter at room temperature.
Caution! Azide compounds of metal ions are potentially explosive. Only a small amount of material should be prepared and it must be handled with care.

\section{2. Synthesis of $\left\{\left[\mathrm{Cu}(\mathrm{L})\left(\mathrm{N}_{3}\right)\right]\right.$. $\left.\left(\mathrm{H}_{2} \mathrm{O}\right)_{0.25}\right\}_{\mathrm{n}}(\mathbf{1})$}

The methanol solution $(4 \mathrm{~mL})$ of the ligand $(9.64$ $\mathrm{mg}, 0.040 \mathrm{mmol}$ ) was carefully layered on the top of the $(4 \mathrm{~mL})$ of $\mathrm{Cu}\left(\mathrm{NO}_{3}\right)_{2} \cdot 3 \mathrm{H}_{2} \mathrm{O}(9.66 \mathrm{mg}, 0.040 \mathrm{mmol})$. The $(0.20 \mathrm{~mol} / \mathrm{L}, 0.4 \mathrm{~mL})$ of $\mathrm{NaN}_{3}$ was gently added as the third layer. The solutions were left for 5 days at room temperature, and complex 1 (7.43 $\mathrm{mg})$ was obtained. Yield: $53 \%$. IR $\left(\mathrm{KBr}, \mathrm{cm}^{-1}\right): 3434,3058,3008,2047$, 1616, 1562, 1498, 1457, 1408, 1378, 1345, 1326, 1311, $1229,1194,1175,1153,1140,1069,1038,1008,868$, 848, 797, 760, 709, 696, 656, 607, 581, 520, 456, 423. Anal. Calcd. For $\mathrm{C}_{12} \mathrm{H}_{10.50} \mathrm{CuN}_{8} \mathrm{O}_{1.25}(\%)$ : C, $41.14 ; \mathrm{H}$, 3.02 ; N, 31.99. Found: C, 41.26; H, 3.01; N, 32.12.

\subsection{Synthesis of $\left\{\left[\mathrm{Zn}(\mathrm{L})\left(\mathrm{N}_{3}\right)\right]\right.$ • $\left.\left(\mathrm{H}_{2} \mathrm{O}\right)_{0.5}\right\}_{\mathrm{n}}(\mathbf{2})$}

Complex $2(5.78 \mathrm{mg})$ was obtained by similar procedure as 1 by using $\mathrm{Zn}\left(\mathrm{NO}_{3}\right)_{2} \cdot 6 \mathrm{H}_{2} \mathrm{O}(11.90 \mathrm{mg}, 0.040$ mmol) instead of $\mathrm{Cu}\left(\mathrm{NO}_{3}\right)_{2} \cdot 3 \mathrm{H}_{2} \mathrm{O}$. Yield: $41 \%$. IR $(\mathrm{KBr}$, $\left.\mathrm{cm}^{-1}\right): 3411,3060,3011,2056,1610,1564,1460,1416$, $1404,1364,1323,1307,1234,1188,1173,1154,1142$, 1089, 1067, 1033, 1022, 1008, 914, 866, 854, 793, 765, 716, 702, 660, 612, 578, 558, 519, 457. Anal. Calcd. For $\mathrm{C}_{12} \mathrm{H}_{11} \mathrm{~N}_{8} \mathrm{O}_{1.5} \mathrm{Zn}(\%): \mathrm{C}, 40.41 ; \mathrm{H}, 3.11 ; \mathrm{N}, 31.42$. Found: C, $40.57 ; \mathrm{H}, 3.09 ; \mathrm{N}, 31.51$.

Table 1. Crystallographic data for 1-3.

\begin{tabular}{llll}
\hline Empirical formula & $\mathbf{1}$ & $\mathbf{2}$ & $\mathbf{3}$ \\
\hline$M_{\mathrm{r}}$ & $\mathbf{C}_{\mathbf{1 2}} \mathbf{H}_{\mathbf{1 0 . 5 0}} \mathbf{C u}_{\mathbf{8}} \mathbf{O}_{\mathbf{1 . 2 5}}$ & $\mathbf{C}_{\mathbf{1 2}} \mathbf{H}_{\mathbf{1 1}} \mathbf{N}_{\mathbf{8}} \mathbf{O}_{\mathbf{1 . 5}} \mathbf{Z n}$ & $\mathbf{C}_{\mathbf{2 4}} \mathbf{H}_{\mathbf{2 2}} \mathbf{C d}_{\mathbf{2}} \mathbf{N}_{\mathbf{1 6}} \mathbf{O}_{\mathbf{3}}$ \\
Crystal system & 350.32 & 356.66 & 807.38 \\
Space group & monoclinic & monoclinic & Triclinic \\
$a(\AA)$ & $P 2_{1} / n$ & $P 2_{1} / n$ & $P \overline{1}$ \\
$b(\AA)$ & $10.1082(6)$ & $10.247(3)$ & $10.3084(18)$ \\
$c(\AA)$ & $14.1898(10)$ & $14.165(4)$ & $11.1749(19)$ \\
$\alpha\left(^{\circ}\right)$ & $10.7272(7)$ & $10.703(3)$ & $14.372(2)$ \\
$\beta\left(^{\circ}\right)$ & 90.00 & 90.00 & $88.687(5)$ \\
$\gamma\left({ }^{\circ}\right)$ & $116.467(2)$ & $115.063(8)$ & $89.140(5)$ \\
$V\left(\AA^{3}\right)$ & 90.00 & 90.00 & $68.924(5)$ \\
$Z$ & $1377.37(16)$ & $1407.3(7)$ & $1544.4(5)$ \\
$\rho_{\mathrm{c}}(\mathrm{g} \mathrm{cm})^{-3)}$ & 4 & 4 & 2 \\
$F(000)$ & 1.689 & 1.683 & 1.736 \\
Data / param. $/$ restr. & 710 & 724 & 796 \\
$T / \mathrm{K}$ & $2708 / 215 / 11$ & $2760 / 215 / 10$ & $6045 / 421 / 4$ \\
$\mu(\mathrm{Mo}-\mathrm{K} \alpha) / \mathrm{mm}^{-1}$ & 298 & 298 & 298 \\
$\mathrm{GOF}(F 2)$ & 1.604 & 1.765 & 1.432 \\
$R 1 \mathrm{a}, w R 2 \mathrm{~b}(I>2 \sigma(I))$ & 1.051 & 1.059 & 1.052 \\
\hline
\end{tabular}

$$
{ }^{\mathrm{a}} R_{1}=\sum|| F_{\mathrm{o}}|| F_{\mathrm{c}}|/ \Sigma| F_{\mathrm{o}} \mid \cdot{ }^{\mathrm{b}} w R_{2}=\left[\sum w\left(F_{\mathrm{o}}^{2} F_{\mathrm{c}}^{2}\right)^{2} / \sum w\left(F_{\mathrm{o}}{ }^{2}\right)\right]^{1 / 2}
$$




\section{4. Synthesis of $\left[\mathrm{Cd}_{2}(\mathrm{~L})_{2}\left(\mathrm{~N}_{3}\right)_{2}\left(\mathrm{H}_{2} \mathrm{O}\right)\right]_{n}(3)$}

Complex $3(7.76 \mathrm{mg})$ was obtained by similar procedure as 1 by using $\mathrm{Cd}\left(\mathrm{NO}_{3}\right)_{2} \cdot 4 \mathrm{H}_{2} \mathrm{O}(12.34 \mathrm{mg}, 0.040$ mmol) instead of $\mathrm{Cu}\left(\mathrm{NO}_{3}\right)_{2} \cdot 3 \mathrm{H}_{2} \mathrm{O}$. Yield: $48 \%$. IR $(\mathrm{KBr}$, $\left.\mathrm{cm}^{-1}\right)$ : 3330, 3079, 2054, 1613, 1568, 1510, 1462, 1404, 1358, 1303, 1233, 1180, 1152, 1137, 1061, 1037, 996, 915, 853, 789, 763, 696, 656, 558, 510, 452. Anal. Calcd. For $\mathrm{C}_{24} \mathrm{H}_{22} \mathrm{Cd}_{2} \mathrm{~N}_{16} \mathrm{O}_{3}(\%)$ : C, $35.70 ; \mathrm{H}, 2.75 ; \mathrm{N}, 27.76$. Found: C, 35.81; H, 2.74; N, 27.87.

\section{5. X-ray crystallography}

The data were collected at $298 \mathrm{~K}$ on a computercontrolled Bruker D8 venture diffractometer equipped with graphite monochromated Mo-K $\alpha$ radiation $(\lambda=$
$0.71073 \AA$ ). The collected diffraction data were reduced using the SAINT program, ${ }^{20}$ and multi-scan absorption corrections were performed via the SADABS program. ${ }^{21}$ The structures were solved by direct methods and refined against $F^{2}$ by full-matrix least-squares methods applying the SHELXL program package. ${ }^{22}$ All of the non-hydrogen atoms were refined anisotropically. In complexes $\mathbf{1}$ and $\mathbf{2}$, the ADPs of N6 and N7 atoms were restrained to be same within a standard deviation of $0.005 \AA$. In total 11 geometric restraints were used in modeling this structure. In complex $\mathbf{3}$, the atoms $\mathrm{O} 3$ were constrained to have the same ADPs as atoms Cd1. Total 4 restraints were used in modeling the structure. The azide ion N13 was disordered over two positions in refined ratio 0.50(4):0.50(4). All the hydrogen atoms bonded to $\mathrm{C}$ atoms were generated geo-

Table 2. Selected bond distances $(\AA)$ and angles $\left(^{\circ}\right)$ for complex $\mathbf{1}$ and $\mathbf{2}$.

\begin{tabular}{|c|c|c|c|}
\hline \multicolumn{4}{|c|}{1} \\
\hline$\overline{\mathrm{Cu} 1-\mathrm{N} 1}$ & $2.0526(17)$ & $\mathrm{Cu} 1-\mathrm{N} 3$ & $1.9310(17)$ \\
\hline $\mathrm{Cu} 1-\mathrm{N} 5^{\mathrm{i}}$ & $2.2876(17)$ & Cu1-N6 & $1.9468(18)$ \\
\hline $\mathrm{Cu} 1-\mathrm{N} 6^{\mathrm{ii}}$ & $2.7755(19)$ & $\mathrm{Cu} 1-\mathrm{O} 1$ & $2.0059(14)$ \\
\hline $\mathrm{O} 1-\mathrm{C} 7$ & $1.278(2)$ & N4-C7 & $1.322(3)$ \\
\hline N3-Cu1-N1 & $79.43(7)$ & $\mathrm{N} 3-\mathrm{Cu} 1-\mathrm{O} 1$ & $79.31(6)$ \\
\hline N6-Cu1-O1 & $100.78(7)$ & N6-Cu1-N1 & $98.57(7)$ \\
\hline $\mathrm{N} 6^{\mathrm{ii}}-\mathrm{Cu} 1-\mathrm{N} 5^{\mathrm{i}}$ & $172.18(6)$ & C7-N4-N3 & $107.39(16)$ \\
\hline \multicolumn{4}{|c|}{2} \\
\hline$\overline{\mathrm{Zn} 1-\mathrm{N} 1}$ & $2.1939(17)$ & $\mathrm{Zn} 1-\mathrm{N} 3$ & $2.0521(17)$ \\
\hline $\mathrm{Zn} 1-\mathrm{N} 5^{\mathrm{i}}$ & $2.1277(17)$ & Zn1-N6 & $2.0009(19)$ \\
\hline $\mathrm{Zn} 1-\mathrm{N} 6^{\mathrm{ii}}$ & $2.618(2)$ & $\mathrm{Zn} 1-\mathrm{O} 1$ & $2.1176(15)$ \\
\hline $\mathrm{O} 1-\mathrm{C} 7$ & $1.271(3)$ & $\mathrm{N} 4-\mathrm{C} 7$ & $1.329(3)$ \\
\hline $\mathrm{N} 3-\mathrm{Zn} 1-\mathrm{N} 1$ & $75.41(7)$ & $\mathrm{N} 3-\mathrm{Zn} 1-\mathrm{O} 1$ & $75.60(6)$ \\
\hline N6-Zn1-O1 & $100.67(7)$ & N6-Zn1-N1 & $105.03(7)$ \\
\hline $\mathrm{N} 6^{\mathrm{ii}}-\mathrm{Zn} 1-\mathrm{N} 5^{\mathrm{i}}$ & $170.70(6)$ & C7-N4-N3 & $108.47(16)$ \\
\hline
\end{tabular}

Symmetry codes: (i) $-x+1 / 2, y-1 / 2,-z+3 / 2$; (ii) $-x+1,-y+1,-z+1$.

Table 3. Selected bond distances $(\AA)$ and angles $\left({ }^{\circ}\right)$ for complex 3.

\begin{tabular}{|c|c|c|c|}
\hline$\overline{\mathrm{Cd} 1-\mathrm{N} 1}$ & $2.575(3)$ & $\mathrm{Cd} 1-\mathrm{N} 3$ & $2.364(3)$ \\
\hline $\mathrm{Cd} 1-\mathrm{O} 1$ & $2.359(3)$ & Cd1-N11 & $2.278(3)$ \\
\hline $\mathrm{Cd} 1-\mathrm{O} 3$ & $2.445(3)$ & $\mathrm{Cd} 1-\mathrm{N} 11^{\mathrm{i}}$ & $2.552(4)$ \\
\hline $\mathrm{Cd} 1-\mathrm{N} 10^{\mathrm{iii}}$ & $2.309(3)$ & $\mathrm{Cd} 2-\mathrm{N} 5$ & $2.311(3)$ \\
\hline $\mathrm{Cd} 2-\mathrm{N} 7$ & $2.408(3)$ & $\mathrm{Cd} 2-\mathrm{N} 8$ & $2.312(3)$ \\
\hline $\mathrm{Cd} 2-\mathrm{O} 2$ & $2.268(3)$ & $\mathrm{Cd} 2-\mathrm{N} 14$ & $2.265(4)$ \\
\hline $\mathrm{Cd} 2-\mathrm{N} 14^{\mathrm{ii}}$ & $2.402(4)$ & $\mathrm{C} 7-\mathrm{O} 1$ & $1.265(5)$ \\
\hline C7-N4 & $1.309(5)$ & C19-O2 & $1.265(5)$ \\
\hline C19-N9 & $1.326(5)$ & & \\
\hline $\mathrm{O} 1-\mathrm{Cd} 1-\mathrm{N} 3$ & $67.62(10)$ & $\mathrm{N} 3-\mathrm{Cd} 1-\mathrm{N} 1$ & $65.28(11)$ \\
\hline $\mathrm{N} 1-\mathrm{Cd} 1-\mathrm{O} 3$ & $72.61(11)$ & $\mathrm{N} 11^{\mathrm{i}}-\mathrm{Cd} 1-\mathrm{O} 3$ & $77.81(11)$ \\
\hline $\mathrm{N} 11^{\mathrm{i}}-\mathrm{Cd} 1-\mathrm{O} 1$ & $76.57(11)$ & $\mathrm{N} 11-\mathrm{Cd} 1-\mathrm{N} 10^{\mathrm{iii}}$ & $164.72(12)$ \\
\hline $\mathrm{O} 2-\mathrm{Cd} 2-\mathrm{N} 8$ & $68.93(11)$ & $\mathrm{N} 14-\mathrm{Cd} 2-\mathrm{O} 2$ & $100.41(14)$ \\
\hline $\mathrm{N} 8-\mathrm{Cd} 2-\mathrm{N} 7$ & $68.20(11)$ & $\mathrm{N} 14-\mathrm{Cd} 2-\mathrm{N} 7$ & $122.34(14)$ \\
\hline $\mathrm{N} 5-\mathrm{Cd} 2-\mathrm{N} 14^{\mathrm{iii}}$ & $159.97(15)$ & C7-N4-N3 & 111.7(3) \\
\hline C19-N9-N8 & $109.5(3)$ & & \\
\hline
\end{tabular}

Symmetry codes: (i) $-x, 1-y, 1-z$; (ii) $1-x, 2-y,-z$; (iii) $x, y, 1+z$. 
metrically and refined isotropically using the riding model. The $\mathrm{H}$ atoms attached to water molecules were fixed by difference Fourier maps with $\mathrm{O}-\mathrm{H}=0.85(2) \AA ̊ ., \mathrm{H} \cdots \mathrm{H}$ $=1.44(2) \AA$ and $U_{\text {iso }}(\mathrm{H})=1.5 U_{\text {eq }}(\mathrm{O})$. The occupancy factors for water molecules in $\mathbf{1}$ and $\mathbf{2}$ were obtained by refinement of occupancy number. Details of data collection and refinements of complexes 1-3 are summarized in Table 1 , selected bond distance and angles are given in Tables 2 and 3.

\section{Results and Discussion}

\section{1. IR Spectroscopy}

The IR spectra of complexes 1-3 (Figure S1) display broad band at about $3300 \sim 3400 \mathrm{~cm}^{-1}$ due to the stretching band of water molecules. ${ }^{23}$ The absence of typical $v(\mathrm{C}=\mathrm{O})$ band of $\mathbf{H L}\left(1662 \mathrm{~cm}^{-1}\right)$ and the appearance of $v(\mathrm{C}-\mathrm{O})$ absorption bands $\left(1616 \mathrm{~cm}^{-1}\right.$ for $1,1610 \mathrm{~cm}^{-1}$ for $\mathbf{2}$, and $1613 \mathrm{~cm}^{-1}$ for 3 ) support the coordination of $\mathbf{H L}$ in the enol form. ${ }^{24}$ The stretching vibration of the azomethine bands for complexes 1-3 are found at 1562, 1564, and $1568 \mathrm{~cm}^{-1}$, respectively. Whereas the same band in the free 1 igand $\mathbf{H L}$ was observed at $1632 \mathrm{~cm}^{-1}$. On complexation the shifts of azomethine $\mathrm{C}=\mathrm{N}$ band towards lower wavenumbers indicates coordination of the azomethine to the metal center. ${ }^{12,25}$ The sharp band of the azide ions are found at $2047 \mathrm{~cm}^{-1}$ for $\mathbf{1}, 2056 \mathrm{~cm}^{-1}$ for $\mathbf{2}$, and 2054 $\mathrm{cm}^{-1}$ for 3 .

\section{2. Structural Analysis}

On the self-assembly process, ligand HL featured keto-enol tautomerism. The structural transformation can be supported by changes of the bond lengths and angles as follows (Tables 2 and 3). ${ }^{12,26,27}$ The bond distances of carbonyl group $\mathrm{C}=\mathrm{O}$ are elongated to $1.278(2) \AA$ in $\mathbf{1}$,

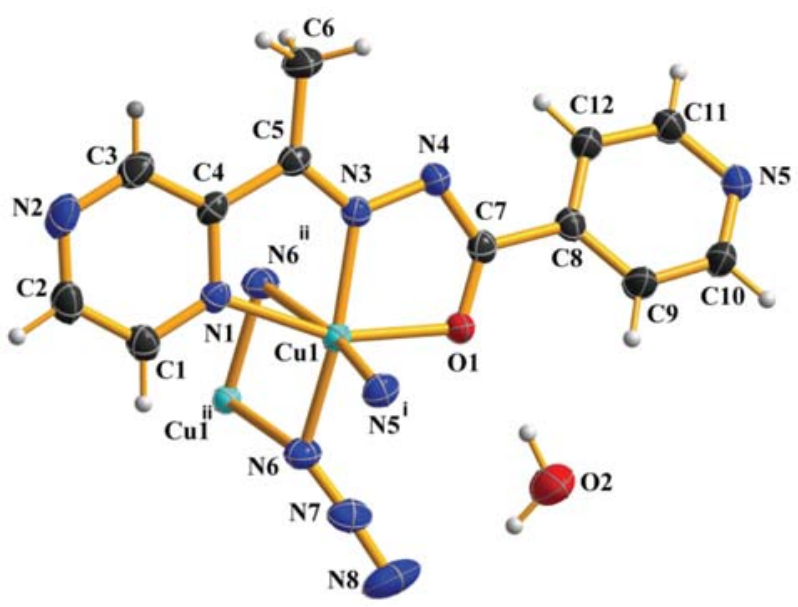

Figure 1. Coordination environment of $\mathrm{Cu}^{\mathrm{II}}$ in $\mathbf{1}$. Symmetry codes: (i) $-x+1 / 2, y-1 / 2,-z+3 / 2$; (ii) $-x+1,-y+1,-z+1$.
1.272(3) $\AA$ in 2, and 1.265(5) $\AA$ in 3, which is the typical $\mathrm{C}-\mathrm{O}$ single bond length; meanwhile the $\mathrm{C}-\mathrm{N}$ bond lengths are shortened to 1.322(3) $\AA$ in $\mathbf{1}, 1.329$ (3) $\AA$ in $\mathbf{2}$, and 1.309(5), 1.326(5) $\AA$ in $\mathbf{3}$, corresponding to the increasing $\pi$-bond order. These bond distance changes are accompanied by shrunk angle of $\mathrm{C}-\mathrm{N}-\mathrm{N}$ being $107.40(16)^{\circ}$ in $\mathbf{1}$, 108.47(17) ${ }^{\circ}$ in $2,111.7(3)^{\circ}$ and $109.5(3)^{\circ}$ in $\mathbf{3}$.

Complexes 1 and $\mathbf{2}$ crystallize in the monoclinic system, space group $P 2_{1} / n$. As shown in Figures 1 and $\mathrm{S} 2$, the two complexes possess very similar coordination environment; so only the structure of $\mathbf{1}$ is described in detail herein.

The asymmetric unit of compound $\mathbf{1}$ is composed of one $\mathrm{Cu}^{\mathrm{II}}$ ion, one deprotonated ligand $\mathrm{L}^{1-}$, one azide anion $\mathrm{N}_{3}^{-}$, and one lattice water molecule. As presented in Figure 1 , the coordination polyhedron around the $\mathrm{Cu}$ (II) center is distorted octahedral. The equatorial plane is surrounded by one nitrogen donor $\mathrm{N} 1$ from pyrazine ring, one nitrogen donor N3 from azomethine, one enolate oxygen donor $\mathrm{O} 1$ and one nitrogen donor N6 from azide ion. The sum of the four equatorial angles $\left(\approx 358.09^{\circ}\right)$ is very close to the ideal value $\left(360.00^{\circ}\right)$, which ensures the planarity of equatorial plane. The copper ion is only $0.0984 \AA$ out of the basal plane. The axial positions are occupied by the pyridyl nitrogen donor $\mathrm{N} 5^{\mathrm{i}}$ from another ligand and azide nitrogen $\mathrm{N}^{\mathrm{ii}}$ (symmetry codes: (i) $-x+1 / 2, y-1 / 2,-z+3 / 2$; (ii) $-x+1,-y+1,-z+1)$. The average bond length of the equatorial plane is $1.9839(17) \AA$, while the average axial bond length is 2.5313(18) $\AA$, thus the coordination sphere for $\mathrm{Cu}$ ion in complex $\mathbf{1}$ is a stretched octahedron.

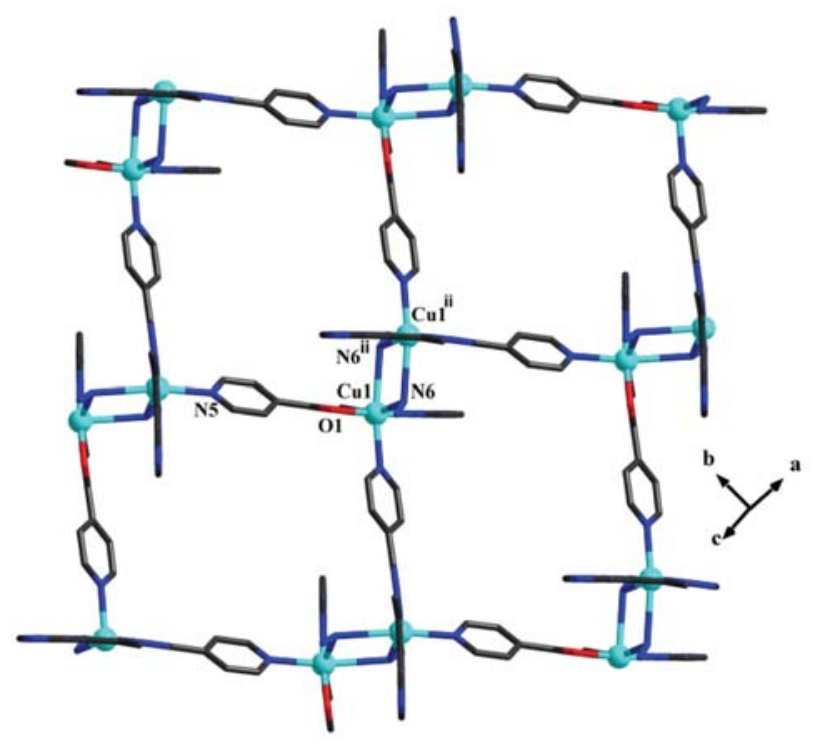

Figure 2. View of the 2D structure of $\mathbf{1}$.

In complex 1, the azide group adopts the asymmetric end-on bridging mode. The $\mathrm{Cu}-\mathrm{N}_{\text {azide }}$ bond length, especially the bond length of $\mathrm{Cu} 1-\mathrm{N} 6^{\mathrm{ii}}(2.7748(19) \AA)$, is 
somewhat longer than those reported in $\mathrm{Cu}$-hydrazoneazide analogues, ${ }^{25,28}$ while it is shorter than that in $\mathrm{Cu}-$ bipyridine- $\left(\mathrm{N}_{3}\right)_{2}$ being 2.849 (4) $\AA .^{29}$ The $\mathrm{Cu}$ (II) centers are bridged by two $\mu_{1,1}-\mathrm{N}_{3}$ to form a planar $\mathrm{Cu}-\left(\mu_{1,1^{-}}\right.$ $\left.\mathrm{N}_{3}\right)_{2}-\mathrm{Cu}$ ring. The $\mathrm{Cu} \cdots \mathrm{Cu}$ distance within the four-membered cyclic units is 3.5837(5) $\AA$. The adjacent $(\mathrm{CuL})_{2}$ $\left(\mu_{1,1}-\mathrm{N}_{3}\right)_{2}$ units are connected with each other via the pyridine N5 atoms forming the 2D sheet structure of 1 (Figure 2). In earlier work, Xu et al. have reported a series of mono-, bi-, tetra-nuclear and 1D chain $\mathrm{Cu}(\mathrm{II})$ complexes derived from $\mathbf{H L}$ and copper salts. ${ }^{19} \mathbf{H L}$ was also in enolic form in those complexes, and acts as $N N O$ donor in mono-, bi-, and tetranuclear complexes. While in the $1 \mathrm{D}$ chain complex $\left\{\left[\mathrm{Cu}_{2}(\mathrm{~L})_{2}\left(\mathrm{NO}_{3}\right)\left(\mathrm{H}_{2} \mathrm{O}\right)_{2}\right] \cdot\left(\mathrm{NO}_{3}\right)\right\}_{\mathrm{n}}, \mathbf{L}$ acts as NNON donor as that in complex $\mathbf{1}$, however the monodentate coordination mode of the nitrate anion limits the further extension of the structure. Therefore the counter anions influence the structures of the complexes efficiently. ${ }^{19}$

In complex 1, the free water molecules are linked to the sheet via hydrogen-bonding interactions $\mathrm{O} 2-\mathrm{H} 2 \mathrm{~A} \cdots \mathrm{N} 7$, $\mathrm{O} 2-\mathrm{H} 2 \mathrm{~A} \cdots \mathrm{N} 8$, and $\mathrm{O} 2-\mathrm{H} 2 \mathrm{~B} \cdots \mathrm{O} 1$ (Figure S3).

Crystal structure study reveals that $\mathbf{3}$ crystallizes in triclinic system, space group $P \overline{1}$. The asymmetric unit of $\mathbf{3}$ consists of two crystallographically independent $\mathrm{Cd}^{2+}$, two deprotonated ligands $\mathrm{L}^{1-}$, two counter anion $\mathrm{N}_{3}^{-}$, and one coordinated water molecule.

As shown in Figure 3, Cd1 center adopts a pentagonal bipyramid coordination geometry. The deprotonated ligand acts as pincer-type ligand, occupying three of the five equatorial coordination sites through pyrazine atom $\mathrm{N} 1$, azomethine atom $\mathrm{N} 3$ and enolate atom $\mathrm{O} 1$. The remaining two sites are held by azide atom $\mathrm{N} 11^{\mathrm{i}}$ and water molecule $\mathrm{O} 3$ (symmetry code: (i) $-x, 1-y, 1-z$ ). The sum of the five equatorial angles $\left(\approx 359.89^{\circ}\right)$ is very close to the ideal value $\left(360^{\circ}\right)$. The nitrogen donors N11 from another azide ion and $\mathrm{N} 10^{\mathrm{iii}}$ from another pyridyl ring occupy the axial positions (symmetry code: (iii) $x, y, 1+z$.). The bond angle of $\mathrm{N} 11-\mathrm{Cd} 1-\mathrm{N} 10^{\mathrm{iii}}$ being $164.72(12)^{\circ}$ suggests a distorted coordination core. Meanwhile the average axial bond length (2.293(3) $\AA$ ) is shorter than the equatorial bond length $(2.459(3) \AA)$ showing a compressed pentagonal bipyramid structure. The $\mathrm{Cd} 2$ center possesses a distorted octahedral coordination environment. The ligand $\mathrm{L}^{1-}$ still serves as pincer ligand occupying the basal plane through N7, N8, and O2. Azide atom N14 takes up the remaining site. The azide donor $\mathrm{N} 14^{\mathrm{ii}}$ (symmetry code: (ii) $1-x, 2-y,-z$ ) and pyridyl donor N5 occupy the axial positions. The angle of $\mathrm{N} 5-\mathrm{Cd} 2-\mathrm{N} 14^{\mathrm{ii}}$ being $159.97(15)^{\circ}$ also deviates markedly from linearity.

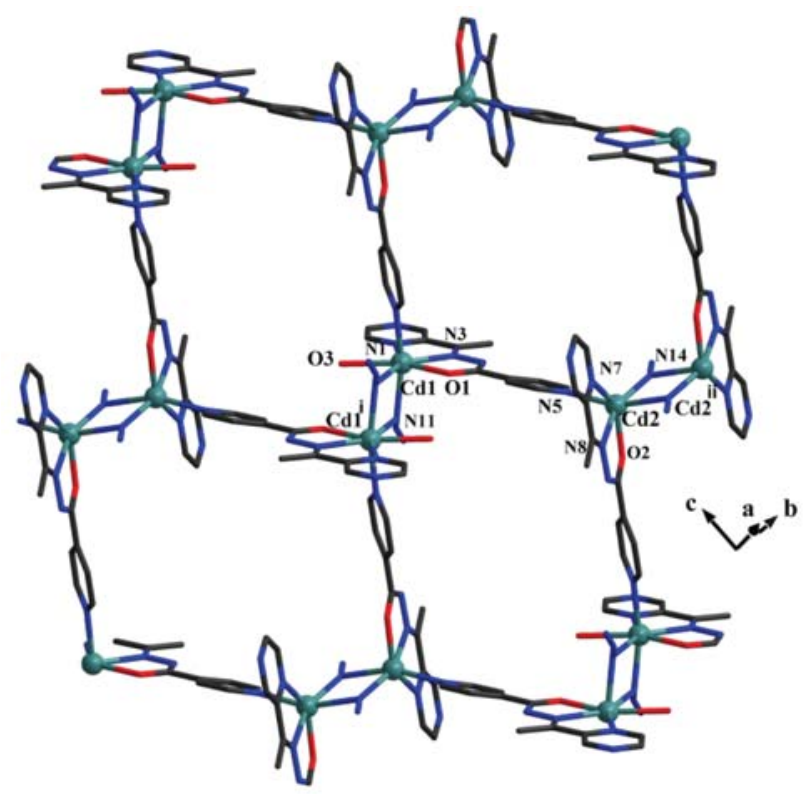

Figure 4. The 2D sheet structure of $\mathbf{3}$.

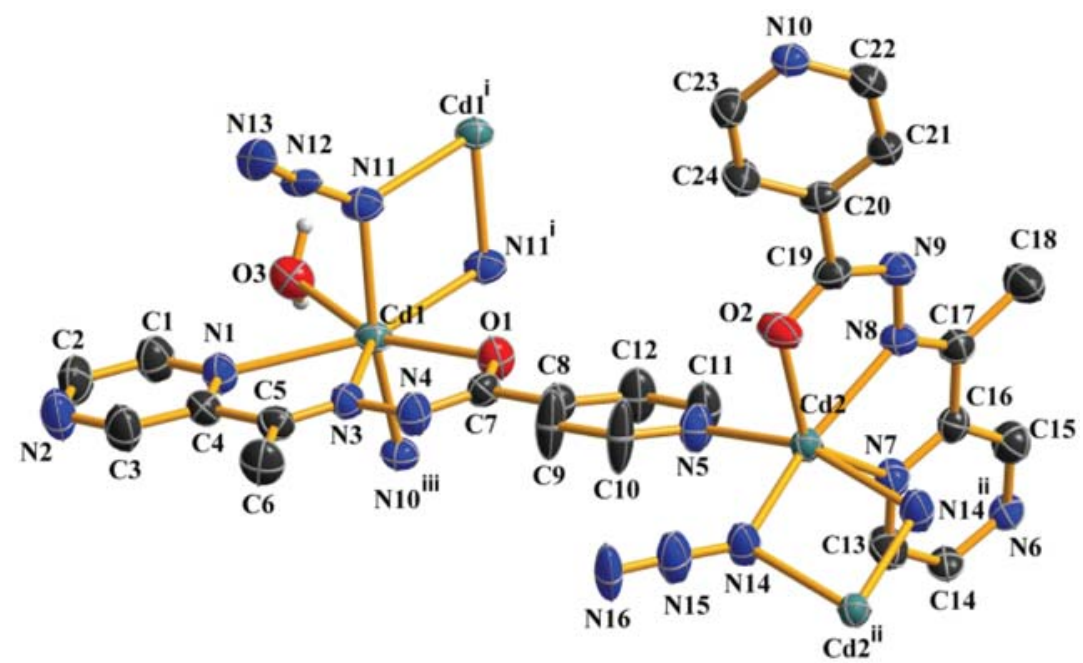

Figure 3. Coordination environment of $\mathrm{Cd}^{\mathrm{II}}$ in $\mathbf{3}$ (H atoms are omitted for clarity). Symmetry codes: (i) $-x, 1-y, 1-z ;$ (ii) $1-x, 2-y,-z$; (iii) $x$, $y, 1+z$. 
The azide ions in $\mathbf{3}$ are more bent than those in $\mathbf{1}$ and 2 with average $\mathrm{N}-\mathrm{N}-\mathrm{N}$ angle of $168.6(3)^{\circ}$. The azide ligands also bridge in an end-on fashion in complex $\mathbf{3}$, which is similar with complexes $\mathbf{1}$ and $\mathbf{2}$. The $\mathrm{Cd}(\mathrm{II})$ centers are bridged by two $\mu_{1,1}-\mathrm{N}_{3}$ with $\mathrm{Cd} \cdots \mathrm{Cd}$ separation of 3.71(1) $\AA$. The $\mathrm{Cd} 1-\mathrm{N} 11-\mathrm{Cd} 1^{\mathrm{i}}$ and $\mathrm{Cd} 2-\mathrm{N} 14-\mathrm{Cd}^{\mathrm{ii}}$ bridging angles are 100.07(13) and $105.06(14)^{\circ}$, respectively. The adjacent $\mathrm{Cd}_{2}\left(\mu_{1,1}-\mathrm{N}_{3}\right)_{2}$ units are connected with each other via the pyridine $\mathrm{N}$ atoms (N5 and N10) forming the 2D sheet structure of $\mathbf{3}$ (Figure 4). In $\mathbf{3}$, the coordinated water molecules are hydrogen bond donors and link these $2 \mathrm{D}$ sheets into $3 \mathrm{D}$ network via $\mathrm{O} 3-\mathrm{H} 3 \mathrm{~B} \cdots \mathrm{O}^{\mathrm{i}}$ and $\mathrm{O} 3-\mathrm{H} 3 \mathrm{C} \cdots \mathrm{N} 6^{\mathrm{iv}}$ (symmetry code: (iv) $-\mathrm{x}+1,-\mathrm{y}+1,-\mathrm{z}+1$ ). (Figure 5).

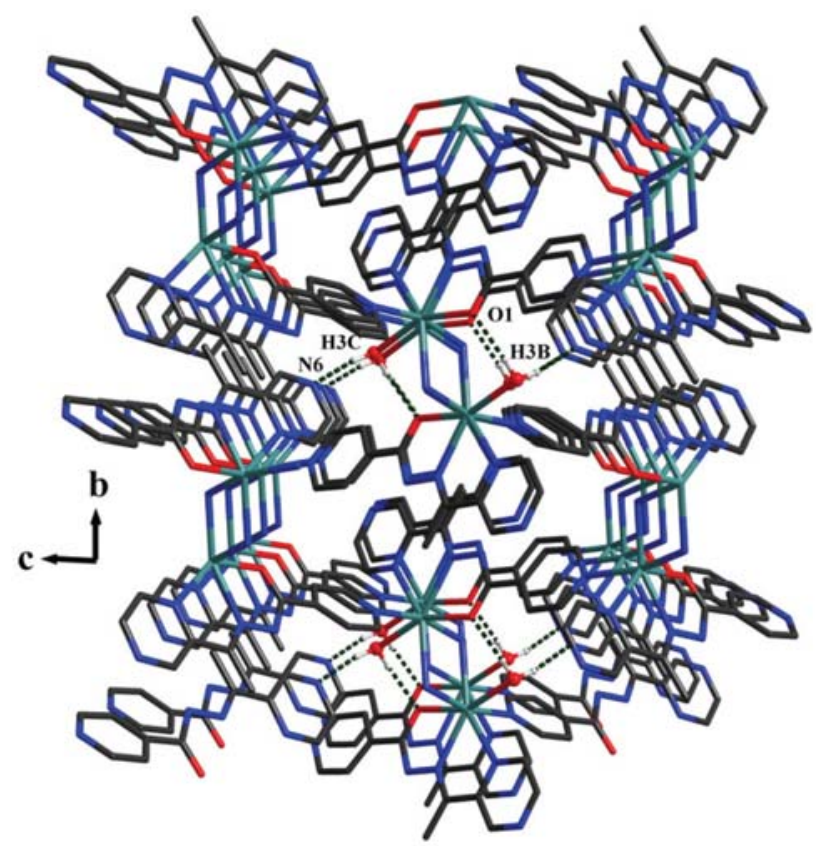

Figure 5. The 3D framework connected by H-bonding interactions in complex 3 .

\section{3. Luminescence Study}

The $\mathrm{d}^{10}$ transition metal based complexes with no d$\mathrm{d}$ transition have intrinsic electronic properties. They are potential candidates for photoactive materials. Here the luminescent properties of $\mathbf{H L}, \mathbf{2}$ and $\mathbf{3}$ were investigated in the solid state at room temperature.

As shown in Figure 7 upon excitation at $402 \mathrm{~nm}$ the free ligand $\mathbf{H L}$ exhibits fluorescent emission centered at $468 \mathrm{~nm}$, which can be attributed to the intra-ligand $\pi^{*}-\pi$ and $\pi^{*}-\mathrm{n}$ transitions. Complexes $\mathbf{2}$ and $\mathbf{3}$ exhibit a little less intense photoluminescence, with emissions around 541 and $551 \mathrm{~nm}$, respectively. $\mathrm{As} \mathrm{Zn}^{2+}$ or $\mathrm{Cd}^{2+}$ ions are difficult to oxidize or reduce owning to their closed shell structure, ${ }^{30,31}$ thus the luminescent emissions of the corresponding complexes $\mathbf{2}$ and $\mathbf{3}$ can be ascribed to the intra-ligand transitions. The red shifts of their emission spectra may be due to

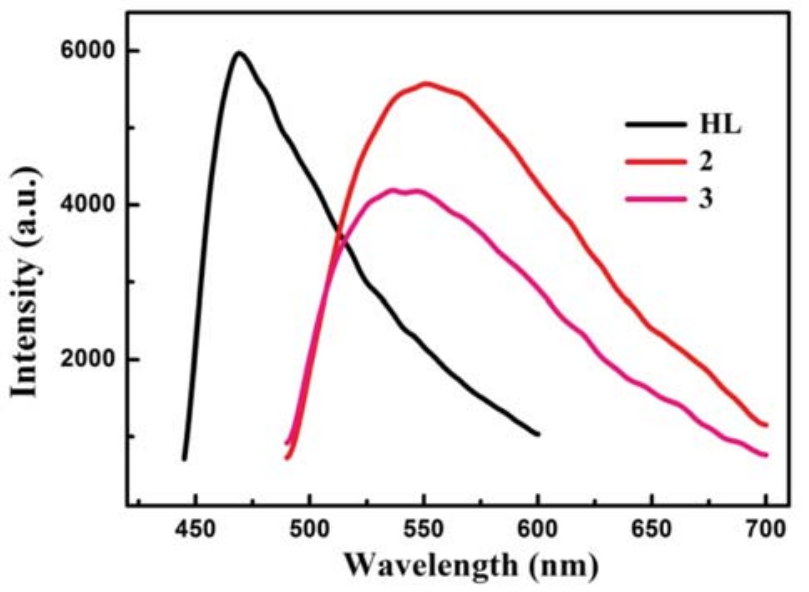

Figure 6. Fluorescence emission properties of the HL and complexes $\mathbf{2}, \mathbf{3}$ in the solid state.

the coordination and hydrogen bonding effect, which can effectively enhance the coplanar arrangement of $\mathbf{H L} .^{32}$

\section{Conclusions}

In this paper, three complexes with 2D layered structures based on multidentate hydrazone ligand $\mathbf{H L}$ and azide salts have been isolated. The asymmetric end-on bridging mode of $\mathrm{N}_{3}^{-}$was found in complexes $1-3$. The monoanionic ligand $\mathbf{L}^{1-}$ coordinated to the metal centers in an enolic form and served as tetradentate NNON type bridging ligand. In complexes $\mathbf{1}$ and $\mathbf{2}$ only intra-sheet hydrogen bonds were observed. The hydrogen bonding interactions between the water molecules and host framework construct a 3D supramolecular network for 3 . In addition, complexes $\mathbf{2}$ and $\mathbf{3}$ exhibit green emission fluorescence behaviors owing to the rigidity of structure.

\section{Supplementary Material}

Crystallographic data (excluding structure factors) for the structural analysis have been deposited with the Cambridge Crystallographic Data Center as supplementary publication Nos. CCDC 1530937 (1), 1530938 (2), and 1530939 (3). Copies of the data can be obtained free of charge via www.ccdc.ac.uk/conts/retrieving.html (or from The Director, CCDC, 12 Union Road, Cambridge CB2 1EZ, UK, Fax: +44-1223-336-033. E-mail: deposit@ ccdc.cam.ac.uk).

\section{Acknowledgment}

This work was supported by the National College Students' Innovative and Entrepreneurial Training Plan of China (201610433115 and 201610433157). 


\section{References}

1. S. Das, H. Kim, K. Kim, J. Am. Chem. Soc. 2009, 131, 3814-3815. https://doi.org/10.1021/ja808995d

2. T. K. Maji, K. Uemura, H. C. Chang, R. Matsuda, S. Kitagawa, Angew. Chem. 2004, 116, 3331-3334. https://doi.org/10.1002/ange.200453923

3. R. Banerjee, H. Furukawa, D. Britt, C. Knobler, M. O'Keeffe, O. M. Yaghi, J. Am. Chem. Soc. 2009, 131, 3875-3877. https://doi.org/10.1021/ja809459e

4. C. Wang, D. Liu, W. Lin, J. Am. Chem. Soc. 2013, 135, 13222-13234. https://doi.org/10.1021/ja308229p

5. P. Wang, J. P. Ma, Y. B. Dong, J. Am. Chem. Soc. 2009, 15, 10432-10445.

6. M. O'Keeffe, O. M. Yaghi, Chem. Rev. 2012, 112, 675-702. https://doi.org/10.1021/cr200205j

7. S. Hou, Q. K. Liu, J. P. Ma, Y. B. Dong, Inorg. Chem. 2013, 52, 3225-3235. https://doi.org/10.1021/ic302716n

8. Y. Bai , J. L. Wang, D. B. Dang, M. M. Li, J. Y. Niu, CrystEngComm. 2012, 14, 1575-1581. https://doi.org/10.1039/C1CE06030A

9. S. Mondal, S. Naskar, A. K. Dey, E. Sinn, C. Eribal, S. R. Herron, S. K. Chattopadhyay, Inorg. Chim. Acta 2013, 398, 98-105. https://doi.org/10.1016/j.ica.2012.12.018

10. Y. F. Liu, Y. P. Liu, K. K. Zhang, Q. L. Ren, J. Qin, Acta Cryst. 2015, C71, 116-121.

11. J. Qin, Q. Yin, S. S. Zhao, J. Z. Wang, S. S. Qian, Acta Chim. Slov. 2016, 63, 55-61. https://doi.org/10.17344/acsi.2015.1918

12. Q. L. Ren, S. S. Zhao, L. X. Song, S. S. Qian, J. Qin, J. Coord. Chem. 2016, 69, 227-237. https://doi.org/10.1080/00958972.2015.1110240

13. Z. Dori, R. F. Ziolo, Chem. Rev. 1973, 73, 247-254. https://doi.org/10.1021/cr60283a003

14. F. A. Mautner, C. Berger, E. Domian, R. C. Fischer, S. S. Massoud, J. Mol. Struct. 2016, 1122, 234-238. https://doi.org/10.1016/j.molstruc.2016.06.004

15. M. Shyamal, A. Panja, A. Saha, Polyhedron 2014, 69, 141-148. https://doi.org/10.1016/j.poly.2013.11.035

16. A. Laachir, S. Guesmi, M. Saadi, L. E. Ammari, O. Mentré, H. Vezin, S. Colis, F. Bentiss, J. Mol. Struct. 2016, 1123, 400-406. https://doi.org/10.1016/j.molstruc.2016.07.053

17. F. Meyer, P. Kircher, H. Pritzkow, Chem. Comm. 2003, 6, 774-775. https://doi.org/10.1039/b211486k
18. B. Shaabani, A. A. Khandar, N. Ramazani, M. Fleck, H. Mobaiyen, L. Cunha-Silva, J. Coord. Chem. 2017, 70, 696-708. https://doi.org/10.1080/00958972.2016.1274028

19. J. Xu, T. Zhou, Z. Q. Xu, X. N. Gu, W. N. Wu, H. Chen, Y. Wang, L. Jia, T. F. Zhu, R. H. Chen, J. Mol. Struct. 2017, $1128,448-454$. https://doi.org/10.1016/j.molstruc.2016.09.016

20. Bruker, SMART and SAINT. Bruker AXS Inc., Madison, Wisconsin, USA, 2002.

21. G. M. Sheldrick, SADABS. Program for Empirical Absorption Correction of Area Detector, University of Göttingen, Germany, 1996.

22. G. M. Sheldrick, Acta Cryst. 2008, A64, 112-122. https://doi.org/10.1107/S0108767307043930

23. J. Qin, N. Lei, H. L. Zhu, J. Coord. Chem. 2014, 67, 12791289. https://doi.org/10.1080/00958972.2014.909591

24. J. Qin, S. S. Zhao, Y. P. Liu, Z. W. Man, P. Wang, L. N. Wang, Y. Xu, H. L. Zhu, Bioorg. Med. Chem. Lett. 2016, 26, 4925-4929. https://doi.org/10.1016/j.bmcl.2016.09.015

25. S. Banerjee, S. Mondal, W. Chakraborty, S. Sen, R. Gachhui, R. J. Butcher, A. M. Z. Slawin, C. Mandal, S. Mitra, Polyhedron 2009, 28, 2785-2793.

https://doi.org/10.1016/j.poly.2009.05.071

26. M. M. Đorđević, D. A. Jeremić, M. V. Rodić, V. S. Simić, I. D. Brčeski, V. M. Leovac, Polyhedron 2014, 68, 234-240. https://doi.org/10.1016/j.poly.2013.10.029

27. S. P. Xu, F. L. Yang, G. Z. Zhu, H. L. Shi, X. L. Li, Polyhedron 2014, 68, 1-9. https://doi.org/10.1016/j.poly.2013.10.013

28. S. Sen, S. Mitra, D. L. Hughes, G. Rosair, C. Desplanches, Polyhedron 2007, 26, 1740-1744. https://doi.org/10.1016/j.poly.2006.12.015

29. G. De Munno, M. G. Lombardi, M. Julve, F. Lloret, J. Faus, Inorg. Chim. Acta 1984, 282, 82-89. https://doi.org/10.1016/S0020-1693(98)00193-5

30. A. Thirumurugan, S. Natarajan, Dalton Trans. 2004, 18, 2923-2928. https://doi.org/10.1039/b408403a

31. L. Zhang, Z. W. Man, Y. Zhang, J. Hong, M. R. Guo, J. Qin, Acta Chim. Slov. 2016, 63, 891-898. https://doi.org/10.17344/acsi.2016.2895

32. J. F. Fang, J. X. Cheng, S. T. Huang, J. Zhang, C. Q. Ni, Y. J. Xiong, Q. Chen, F. F. Zhu, Y. Li, S. T. Yue, Z. Anorg. Allg. Chem. 2015, 641, 2657-2663.

https://doi.org/10.1002/zaac.201500613

\section{Povzetek}

Sintetizirali smo tri kovinsko-organske koordinacijske polimere $\left\{\left[\mathrm{Cu}(\mathrm{L})\left(\mathrm{N}_{3}\right)\right] \cdot\left(\mathrm{H}_{2} \mathrm{O}\right)_{0.25}\right\}_{\mathrm{n}}(\mathbf{1}),\left\{\left[\mathrm{Zn}(\mathrm{L})\left(\mathrm{N}_{3}\right)\right] \cdot\left(\mathrm{H}_{2} \mathrm{O}\right)_{0.5}\right\}_{\mathrm{n}}$ (2) in $\left[\mathrm{Cd}_{2}\left(\mathrm{~L}_{2}\left(\mathrm{~N}_{3}\right)_{2}\left(\mathrm{H}_{2} \mathrm{O}\right)\right]_{\mathrm{n}}(3) \mathrm{z}\right.$ uporabo hidrazonskega liganda $N^{\prime}$-(1-(pirazin-2-il)etiliden)izonikotinohidrazida (HL), $\mathrm{NaN}_{3}$ in ustreznega kovinskega nitrata. Komplekse smo okarakterizirali z elementno analizo, IR spektroskopijo in monokristalno rentgensko difrakcijo. Vsi trije kompleksi imajo 2D koordinacijsko mrežo, kjer ima $\mathbf{L}^{1-}$ vlogo NNON štiriveznega liganda, azidni anion pa je mostovni ligand. V kompleksih $\mathbf{1}$ in $\mathbf{2}$ so prisotne samo vodikove vezi znotraj plasti, medtem ko v kompleksu 3 vodikove vezi med vodo in gostiteljsko mrežo tvorijo 3D mrežo. Kompleksa 2 in 3 intenzivno fluorescirata $\mathrm{v}$ trdnem stanju pri sobni temperaturi. 